\title{
Penerapan Metode IPA dan PGCV untuk Mengukur Tingkat Kepuasan Konsumen Coffee Shop
}

\author{
P E Rizqiyah ${ }^{1 *}$, R T Subagio ${ }^{2}$, T E Putri ${ }^{3}$ \\ Teknik Informatika, Fakultas Teknologi Informasi, Universitas Catur Insan Cendekia ${ }^{123}$ \\ Jl. Kesambi No.202, Kota Cirebon, 45133, Indonesia \\ putri.erizqiyah@gmail.com ${ }^{1 *}$, ridho.taufiq@cic.ac.id ${ }^{2}$, tiara.ekaputri@cic.ac.id ${ }^{3}$ \\ diterima: 18 Juli 2021 \\ direvisi: 17 Agustus 2021 \\ dipublikasi: 1 September 2021
}

\begin{abstract}
Abstrak
Upaya untuk mengetahui tingkat kinerja kualitas pelayanan dan kualitas produk di Oksigen Coffee saat ini dilakukan survei kepuasan konsumen, survei dilakukan secara manual dan bentuk wawancara belum berdasarkan indikator-indikator sebagai standar yang diperlukan untuk keseragaman materi survei sehingga mengalami kesulitan untuk melakukan analisa lebih lanjut. Maka dibutuhkan adanya sistem untuk mengukur tingkat kepuasan konsumen dengan menerapkan metode analisis yang mempertimbangkan tingkat kepentingan atau harapan dari responden. Tujuan dari penelitian ini adalah menerapkan penggabungan 2 metode analisa yaitu metode IPA yang digunakan untuk mengetahui atribut yang diperbaiki atau dikurangi berdasarkan letak pada pemetaan kuadrannya, sedangkan metode PGCV digunakan untuk mengetahui urutan prioritas perbaikan atribut yang harus diperbaiki atau ditingkatkan berdasarkan nilai potensialnya serta hasil dari metode PGCV merupakan hasil akhir dalam pengukuran tingkat kepuasan konsumen. Hasil penelitian ini adalah sistem yang mampu mengetahui tingkat kepuasan konsumen berdasarkan tingkat kinerja dan tingkat kepentingan atribut yang harus diperbaiki atau dikurangi dan urutan prioritas perbaikannya.
\end{abstract}

Kata kunci: pengukuran tingkat kepuasan konsumen; coffee shop; IPA; PGCV; kuesioner

\begin{abstract}
Efforts to determine the level of service quality performance and product quality at Oksigen Coffee are currently conducting a consumer satisfaction survey, the survey is carried out manually and the interview form is not based on indicators as the standard required for uniformity of survey material so that it is difficult to conduct further analysis. So we need a system to measure the level of consumer satisfaction by applying an analytical method that considers the level of interest or expectations of the respondents. The purpose of this study is to apply the combination of 2 analytical methods, namely the IPA method which is used to determine the attributes that are improved or reduced based on the location on the quadrant mapping, while the PGCV method is used to determine the priority order of attribute improvements that must be improved or increased based on their potential values and the results of the method. PGCV is the final result in measuring the level of customer satisfaction. The result of this study is a system that is able to determine the level of consumer satisfaction based on the level of performance and the level of importance of the attributes that must be improved or reduced and the order of priority for improvement.
\end{abstract}

Keywords: measurement of consumer satisfaction level; coffee shop; IPA; PGCV; questionnaire

\section{Pendahuluan}

Kopi (Coffee) adalah minuman hasil seduhan biji kopi yang telah melalui proses roasting, kopi merupakan minuman yang sangat digemari di seluruh dunia termasuk Indonesia yang memiliki konsumen kopi yang sangat tinggi, selain itu Indonesia merupakan salah satu negara penghasil kopi terbanyak dan terbaik dalam jenis kopi robusta dan arabika yang memiliki kualitas yang sangat baik, saat ini menikmati kopi sudah menjadi gaya hidup untuk anak generasi millenials [1]. Semakin besar peminat kopi sehingga menjadi peluang untuk membuka bisnis kedai kopi di Indonesia, sehingga dalam dunia bisnis semakin bersaing 
untuk memberikan layanan dan kualitas produk yang terbaik untuk konsumennya [2], salah satu upaya untuk mengetahui tingkat kepuasan konsumen terhadap layanan dan kualitas produk yang telah didapatkannya adalah dengan menggunakan sistem analisa kepuasan konsumen dan rata-rata penyedia jasa dibidang kuliner belum menyediakannya.

Upaya untuk meningkatkan jumlah konsumen dan omset merupakan bagian penting dalam bisnis kuliner, khususnya Oksigen Coffee sehingga diperlukan landasan untuk melakukan peningkatannya. Salah satu landasan tersebut adalah melalui umpan balik dari konsumen. Berdasarkan informasi yang penulis dapatkan dari bagian Operasional Oksigen Coffee, saat ini untuk mengetahui pendapat konsumen tentang kinerja layanan dan kualitas produk yang ditawarkan masih dilakukan dengan cara berbincang secara langsung dengan konsumen, hal ini seringkali mengakibatkan kesulitan untuk mengingat kembali tentang banyaknya opini konsumen yang diwawancara karena tidak terekam dengan baik. Selain itu, bentuk wawancara yang dilakukan belum berdasarkan indikator-indikator sebagai standar yang diperlukan serta keseragaman materi wawancara atau survei sehingga mengalami kesulitan untuk melakukan analisa lebih lanjut dalam upaya peningkatan layanan dan kualitas produk atau improvisasi menu yang banyak disukai konsumen, sehingga dapat merekomendasikan tempat ini sebagai Coffee Shop yang sangat direkomendasikan bagi pecinta kopi. Salah satu upaya untuk meningkatkan jumlah konsumen dan omset dibutuhkan sistem untuk merekam dan menganalisa dengan cepat data umpan balik (feedback) konsumen terhadap kepuasan konsumen yang memiliki aspek penilaian kepentingan atau harapan konsumen dan kinerja layanan Oksigen Coffee.

Dengan adanya permasalahan tersebut maka penulis tertarik untuk membuat sistem yang mampu untuk menganalisa dan mengukur tingkat kepuasan konsumen Coffee Shop, menggunakan kombinasi dari metode Importance Performance Analysis (IPA) dan Potential Gain in Customer Value (PGCV). Penggunaan metode IPA dan PGCV untuk mengukur tingkat kepuasan konsumen ini dikarenakan memiliki keterkaitan yang saling mendukung untuk menghasilkan nilai tingkat kepuasan konsumen secara detail dengan menampilkan atribut mana saja yang harus diperbaiki atau dikurangi dan mengurutkan atribut yang menjadi prioritas perbaikan berdasarkan nilai bobot potensialnya.

Metode Importance Performance Analysis (IPA) sudah diterapkan atau digunakan oleh beberapa penelitian terdahulu, seperti penelitian pada analisis kepuasan konsumen terhadap kualitas produk kopi dan kualitas pelayanan, penerapan pada penelitian tersebut dapat menampilkan persentase atribut yang diperbaiki atau dipertahankan dan atribut yang dikurangi, berdasarkan posisi pada kuadran yang menyesuaikan dengan nilai hasil akhir [3]. Selain itu, pada penelitian lain yang menerapkan metode IPA dapat disimpulkan bahwa metode ini dapat memberikan hasil nilai kesesuaian dari yang terendah sampai tertinggi terhadap keseluruhan dimensi dan memberikan keputusan perbaikan terhadap atribut yang harus diperbaiki atau dipertahankan dan menampilkan atribut yang dikurangi [4]. Sedangkan pada penelitian terdahulu yang menerapkan metode Potential Gain in Customer Value (PGCV) dapat disimpulkan bahwa metode ini mampu memberikan nilai bobot yang perlu diperbaiki atau diprioritaskan, selain itu untuk nilai indeks kepuasan diurutkan sesuai dari bobot prioritas perbaikannya (nilai potensialnya) [5], [6]. Dari jurnal penelitian yang digunakan sebagai referensi untuk membantu mempermudah penulis, hanya sebatas teori dan menganalisa tingkat kepuasan konsumen yang didalamnya menerapkan metode, namun pada penelitian tersebut hanya memakai bantuan software SPPS dalam proses menganalisanya untuk menghasilkan nilai statistik sehingga hal ini tidak efisien karena memerlukan biaya. Dari jurnal-jurnal penelitian tersebut dapat disimpulkan bahwa tidak ada penelitian yang memiliki output yang membangun sistem untuk menganalisa dan mengukur tingkat kepuasan konsumen berbasis web secara individu. 
Berdasarkan permasalahan yang sudah diuraikan, maka tujuan dari penelitian yang akan dilakukan oleh penulis adalah membuat sistem yang mampu untuk mengukur dan menganalisa tingkat kepuasan konsumen berbasis web dan menerapkan metode gabungan dari Importance Performance Analysis (IPA) dan Potential Gain in Customer Value (PGCV). Pada penerapan metode gabungan ini akan melalui 4 tahap yaitu mencari indeks kepuasan secara keseluruhan, pengelompokan atribut pertanyaan yang sudah dihitung pada masing-masing kuadran, menampilkan atribut yang diperbaiki atau dipertahankan dan atribut yang dikurangi, serta menampilkan urutan atribut yang ditingkatkan atau diperbaiki berdasarkan bobot prioritas perbaikannya. Dengan harapan hasil analisis kepuasan yang ditampilkan pada sistem yang dibuat dapat membantu pihak Oksigen Coffee dalam mengambil keputusan untuk meningkatkan kualitas pelayanan dan kualitas produk untuk kedepannya.

\section{Kajian Pustaka}

Kajian pustaka dalam penelitian ini berkaitan dengan kualitas dan kinerja, kepuasan pelanggan, pengukuran kepuasan pelanggan, coffee shop, dan UML, yang akan dijelaskan sebagai berikut :

\subsection{Kualitas dan Kinerja}

Kualitas pelayanan berfokus pada upaya untuk pemenuhan kebutuhan dan keinginan konsumen serta ketepatan penyampaiannya untuk mengimbangi harapan dari konsumen. Kualitas pelayanan merupakan tingkat keunggulan yang diharapkan dan pengendali atas keunggulan tersebut untuk memenuhi kebutuhan dari konsumennya. Sedangkan untuk kualitas produk merupakan suatu fungsi beserta sifat dari produk yang dapat memenuhi selera atau kebutuhan dari konsumen sesuai harga yang dibayarkan, kualitas produk yaitu kemampuan uatu barang untuk memberikan hasil atau kinerja yang sesuai bahkan melebihi dari apa yang menjadi harapan konsumen [7].

\subsection{Kepuasan Pelanggan}

Kepuasan pelanggan atau konsumen merupakan perbedaan antara harapan dan persepsi terhadap yang pelayanan yang diberikan oleh perusahaan, selain itu kepuasan pelanggan adalah perasaan seseorang terhadap kinerja dari suatu produk yang dirasakan sesuai dengan harapannya [8].

\subsection{Pengukuran Kepuasan Pelanggan}

Pengukuran kepuasan pelanggan dapat dilakukan dengan beberapa cara seperti : menyediakan sarana kotak untuk menampung keluhan dari pelanggan tersebut, melalui survei kepuasan pelanggan yang dapat dilakukan dengan teknik (directly reported satisfaction, derived dissatisfaction, importance performance analysis) dan menggunakan cara ghost shopping [9].

\subsection{Coffee Shop}

Merupakan tempat yang menjual minuman khusus jenis kopi dan jenis minuman lainnya berserta makanan ringan, para penikmat kopi akan mendapatkan minuman yang berkualitas dan fasilitas yang menunjang pada tempat tersebut [10].

\subsection{Unified Modeling Language}

UML singkatan dari Unified Modeling Language merupakan sekumpulan alat yang digunakan untuk melakukan abstraksi terhadap sebuah sistem atau perangkat lunak berbasis 
objek. $U M L$ menjadi salah satu cara untuk mempermudah pengembangan aplikasi yang berkelanjutan. Unified Modeling Language (UML) merupakan standard modeling language yang terdiri dari kumpulan-kumpulan diagram, dikembangkan untuk membantu para pengembang sistem dan software agar bisa menyelesaikan tugas-tugas. UML terdiri dari Use Case Diagram, Activity Diagram, Class Diagram, Sequence Diagram dan Flow Map [11].

\section{Metode Penelitian}

\subsection{Metode Pengembangan Perangkat Lunak}

Bahan yang digunakan pada penelitian ini bersumber pada data primer dan data sekunder. Data primer didapatkan dari tempat penelitian yaitu dengan melakukan wawancara, sedangkan untuk data sekunder didapatkan melalui literatur artikel, jurnal referensi dan skripsi yang membahas mengenai analisa kepuasan konsumen yang menerapkan metode Importance Performance Analysis (IPA) dan Potential Gain in Customer Value (PGCV). Variabel yang digunakan pada penelitian analisis kepuasan konsumen ini menggunakan 5 indikator utama yaitu : reliability (keandalan), responsiveness (daya tanggap), assurance (jaminan), empathy (empati) dan tangibles (bukti fisik).

Metode pengembangan perangkat lunak yang digunakan pada skripsi penulis, menggunakan metode waterfall yang merupakan sebuah metode pengembangan software sekuensial, pada metode ini memiliki 5 (lima) tahap saling berkaitan [11], sebagai berikut :

1. Requirement (Analisa Kebutuhan Sistem)

Tahap ini melakukan pengumpulan data melalui observasi dan sesi wawancara secara langsung dengan bagian Operasional Oksigen Coffee mengenai sejarah dan proses yang sedang berjalan saat ini, beserta penentuan pertanyaan yang akan diterapkan pada 5 indikator utama yaitu reliability (keandalan), responsiveness (daya tanggap), assurance (jaminan), empathy (empati) dan tangibles (bukti fisik).

2. Design (Desain)

Tahap selanjutnya adalah tahapan desain, dimana pada tahap ini merupakan proses dari analisis kuesioner menggunakan perhitungan manual yang menerapkan metode Importance Performance Analysis (IPA) dan Potential Gain in Customer Value (PGCV). Selanjutnya, membuat perancangan alur sistem secara keseluruhan menggunakan Unified Modelling Language (UML) yang terdiri dari Use Case, Flow of Event, Activity Diagram, Sequence Diagram, Class Diagram dan desain input output. Sehingga pada tahapan ini menghasilkan analisis kuesioner dan data yang menggambarkan aktivitas user didalam sistem tersebut.

3. Implementation (Implementasi)

Tahap selanjutnya adalah tahapan implementasi, dimana pada tahap ini merupakan proses untuk menerjemahkan keseluruhan desain sistem yang telah dirancangan menjadi kode-kode program sehingga menghasilkan suatu sistem secara keseluruhan.

4. Verification (Verifikasi)

Tahap selanjutnya adalah tahapan verifikasi, pada tahapan ini merupakan pengujian terhadap sistem yang telah dibuat untuk memastikan kesesuaian dengan tahap analisis dan desain yang telah dilakukan, pengujian sistem dilakukan dengan Black Box.

5. Maintenance (Perawatan)

Pada tahap terakhir adalah tahapan perawatan atau pemeliharaan sistem, apabila ditemukan kesalahan yang tidak terdeteksi pada tahap verifikasi. Setelah melewati tahap terakhir ini akan menghasilkan sistem yang lebih baik.

\subsection{Kerangka Sistem}


Berdasarkan Gambar 1. dalam pembuatan sistem dibutuhkan input yaitu data awal yang akan digunakan sebagai bahan untuk melakukan pengukuran tingkat kepuasan konsumen terhadap tingkat kinerja dan tingkat kepentingan. Dalam sistem ini input awal adalah kuesioner kepuasan konsumen.

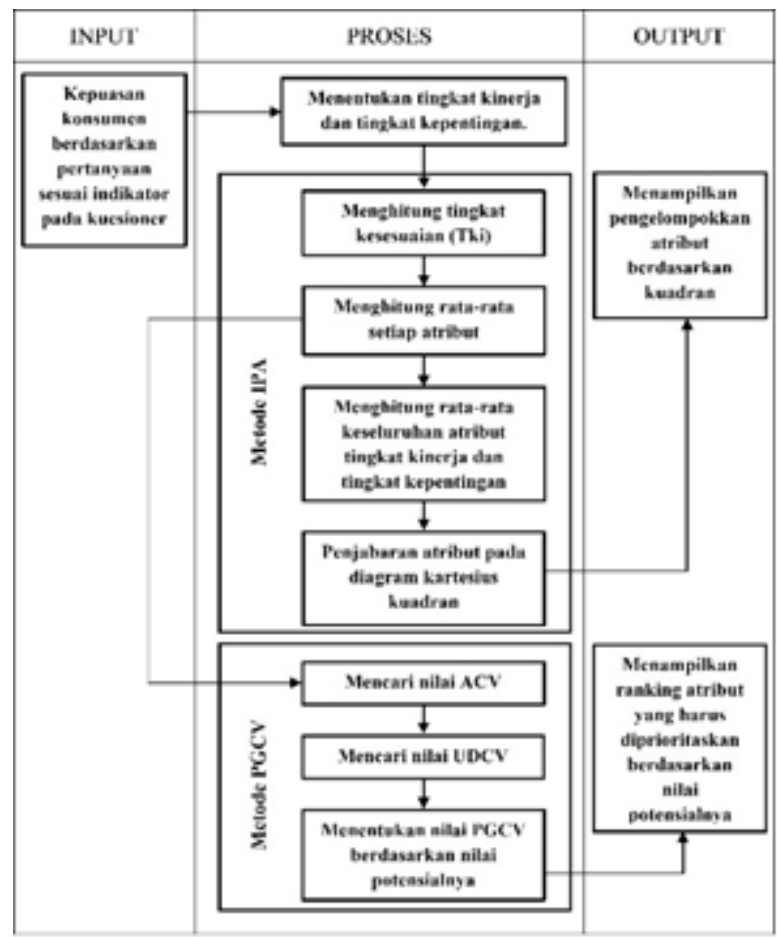

Gambar 1. Kerangka Sistem

Setelah mendapatkan hasil survey yang didapatkan dari kuesioner yang telah diisi oleh konsumen Oksigen Coffee, selanjutnya sistem akan melakukan proses yang terdiri pada beberapa tahapan, sebagai berikut :

1. Tahap menentukan Tingkat Kinerja atau Kenyataan (Performance) dan Tingkat Kepentingan atau Harapan (Importance), pada penilaian menggunakan skala likert untuk menetapkan bobot dari angka 1 sampai angka 4.

2. Tahap perhitungan tingkat kesesuaian (Tki) yang dihasilkan dari tingkat kinerja dan tingkat kepentingan konsumen, dapat dilihat dari Persamaan 1.

$\mathbf{T k i}=\frac{\boldsymbol{X}_{\boldsymbol{i}}}{\boldsymbol{Y}_{\boldsymbol{i}}} \times 100 \%$

Keterangan :

$\mathrm{TK}_{\mathrm{i}}$ : Tingkat kesesuaian responden.

$\mathrm{X}_{\mathrm{i}} \quad$ : Skor penilaian kinerja Coffee Shop.

$\mathrm{Y}_{\mathrm{i}} \quad$ : Skor penilaian harapan responden.

3. Tahap perhitungan rata-rata setiap atribut, yang akan menghasilkan skor rata-rata tingkat kinerja $(\bar{X})$ dan skor rata-rata tingkat kepentingan $(\bar{Y})$, dapat dilihat dari Persamaan 2.

$\bar{X}=\sum \frac{X i}{n} \quad \bar{Y}=\sum \frac{Y i}{n}$

Keterangan :

$\bar{X} \quad$ : Skor rata-rata tingkat kinerja.

$\bar{Y} \quad$ : Skor rata-rata tingkat kepentingan.

$n$ : Jumlah responden 
4. Tahap perhitungan rata-rata keseluruhan atribut tingkat kinerja dan tingkat kepentingan, sehingga hasilnya dapat dijadikan batasan dalam pembagian kuadran, dapat dilihat dari Persamaan 3.

$\overline{\bar{X}}=\sum \frac{\overline{X_{i}}}{k} \quad \overline{\bar{Y}}=\sum \frac{\overline{Y_{i}}}{k}$

Keterangan :

$\overline{\bar{X}} \quad$ : Rata-rata seluruh atribut tingkat kinerja.

$\overline{\bar{Y}} \quad$ : Rata-rata seluruh atribut tingkat kepentingan.

$k \quad$ : Banyaknya atribut yang mempengaruhi kepuasanya konsumen.

5. Tahap terakhir dalam pengukuran kepuasan menggunakan metode IPA yaitu penjabaran atribut atau pemetaan kuadran yang akan dibagi menjadi 4 kuadran.

6. Selanjutnya, tahap pencarian atau perhitungan nilai ACV yang menampilkan nilai yang tercapai dari kepuasan konsumen, dapat dilihat dari Persamaan 4.

$A C V=X . Y$

Keterangan :

ACV : Nilai pencapaian konsumen.

$\mathrm{X}$ : Skor rata-rata tingkat kepuasan (kenyataan).

Y : Skor rata-rata tingkat kepentingan (ekspetasi).

7. Tahap pencarian atau perhitungan nilai UDCV, yang diperoleh dari hasil perkalian antara nilai Importance yang telah dipilih dengan nilai Performance yang tertinggi pada skalanya, dapat dilihat dari Persamaan 5.

$U D C V=Y . X \max$

Keterangan :

Y : Skor rata-rata tingkat kepentingan (importance).

Xmax : Nilai performance maksimal pada skala likert.

8. Tahap terakhir dari pengukuran tingkat kepuasan konsumen, yaitu menentukan nilai PGCV. Pada tahap ini akan dilakukan perankingan terhadap nilai potensial yang tertinggi akan dijadikan sebagai prioritas untuk dilakukan perbaikan, dapat dilihat dari Persamaan 6.

$P G C V=U D C V-A C V$

Setelah proses perhitungan tingkat kepuasan konsumen Oksigen Coffee terhadap kinerja layanan dan kualitas produk, berdasarkan tingkat kinerja dan tingkat kepentingannya menggunakan metode Importance Performance Analysis (IPA) dan Potential Gain in Customer Value (PGCV), sistem akan menghasilkan output survei kepuasan konsumen yang sudah dalam klasifikasi tingkat kepuasan yang nanti akan ditinjau oleh bagian operasional sebagai admin. Interprestasi tingkat kepuasan akan disajikan dalam bentuk angka beserta persentase.

\subsection{Analisis Sistem}

\section{Hasil dan Pembahasan}

Analisa sistem merupakan penjabaran dari sistem informasi yang sudah terbentuk kedalam bagian komponennya sebagai upaya untuk melakukan identifikasi dan proses evaluasi pada permasalahan yang terjadi dan kebutuhan-kebutuhan yang diharapkan sehingga dapat diusulkan perbaikannya, sebagai berikut :

1. Tingkat kinerja atau kenyataan (Performance)

Pedoman yang akan digunakan konsumen untuk menilai tingkat kinerja yaitu dengan menggunakan skala likert yang didalamnya terdapat angka 1 sampai 4, dapat dilihat pada Tabel 1 : 
Tabel 1. Tingkat Kinerja

\begin{tabular}{|c|c|c|}
\hline No & Keterangan & Nilai \\
\hline 1 & Sangat Baik & 4 \\
\hline 2 & Baik & 3 \\
\hline 3 & Cukup & 2 \\
\hline 4 & Kurang & 1 \\
\hline
\end{tabular}

2. Tingkat kepentingan atau harapan (Importance)

Pedoman yang akan digunakan konsumen untuk menilai tingkat kepentingan yaitu dengan menggunakan skala likert yang didalamnya terdapat angka 1 sampai 4, dapat dilihat pada Tabel 2 :

Tabel 2. Tingkat Kepentingan

\begin{tabular}{|c|l|c|}
\hline No & \multicolumn{1}{|c|}{ Keterangan } & Nilai \\
\hline 1 & Sangat Penting & 4 \\
\hline 2 & Penting & 3 \\
\hline 3 & Cukup & 2 \\
\hline 4 & Kurang & 1 \\
\hline
\end{tabular}

3. Daftar pertanyaan beserta indikator yang akan digunakan dalam menentukan tingkat kepuasan konsumen Oksigen Coffee, dapat dilihat pada Tabel 3 :

Tabel 3. Daftar Pertanyaan

\begin{tabular}{|c|c|c|c|}
\hline $\begin{array}{l}\text { Kode } \\
\text { Indikator }\end{array}$ & Indikator & Pertanyaan & Kode \\
\hline \multirow{4}{*}{ A } & \multirow{4}{*}{ Reliability } & $\begin{array}{l}\text { Minuman dan makanan sesuai gambar } \\
\text { pada daftar menu. }\end{array}$ & A1 \\
\hline & & $\begin{array}{l}\text { Rasa minuman Oksigen Coffee } \\
\text { memiliki rasa yang khas dan konsisten. }\end{array}$ & $\mathrm{A} 2$ \\
\hline & & $\begin{array}{l}\text { Keseimbangan cita rasa Coffee yang } \\
\text { disajikan Oksigen Coffee }\end{array}$ & A3 \\
\hline & & $\begin{array}{l}\text { Oksigen Coffee memiliki beragam } \\
\text { variasi produk/menu. }\end{array}$ & A4 \\
\hline \multirow{5}{*}{$\mathrm{B}$} & \multirow{5}{*}{ Responsiviness } & $\begin{array}{l}\text { Pegawai mampu berkomunikasi } \\
\text { dengan baik pada saat menawarkan } \\
\text { menu yang tersedia di Oksigen Coffee }\end{array}$ & B1 \\
\hline & & Kemudahan dalam proses transaksi & $\mathrm{B} 2$ \\
\hline & & $\begin{array}{l}\text { Proses penyajian pesanan tidak } \\
\text { membutuhkan waktu lama }\end{array}$ & B3 \\
\hline & & $\begin{array}{l}\text { Ketanggapan Pegawai jika konsumen } \\
\text { meminta bantuan }\end{array}$ & B4 \\
\hline & & $\begin{array}{l}\text { Pegawai dengan cepat membersihkan } \\
\text { meja yang baru saja kosong }\end{array}$ & B5 \\
\hline \multirow{2}{*}{$\mathrm{C}$} & \multirow{2}{*}{ Assurance } & $\begin{array}{l}\text { Cita rasa minuman dan makanan } \\
\text { sesuai dengan harga yang dibayar }\end{array}$ & $\mathrm{C} 1$ \\
\hline & & $\begin{array}{l}\text { Kebersihan dalam prosess pembuatan } \\
\text { pesanan }\end{array}$ & $\mathrm{C} 2$ \\
\hline
\end{tabular}




\begin{tabular}{|c|c|l|c|}
\hline \multirow{5}{*}{} & $\begin{array}{l}\text { Kebersihan lingkungan Oksigen } \\
\text { Coffee }\end{array}$ & C3 \\
\cline { 3 - 4 } & $\begin{array}{l}\text { Kenyamanan dan keamanan Oksigen } \\
\text { Coffee }\end{array}$ & C4 \\
\cline { 3 - 4 } & $\begin{array}{l}\text { Kerapihan serta kenyaman tempat } \\
\text { duduk yang disediakan }\end{array}$ & C5 \\
\hline \multirow{4}{*}{ Empathy } & $\begin{array}{l}\text { Menyapa dan tersenyum terhadap } \\
\text { konsumen yang datang }\end{array}$ & D1 \\
\cline { 3 - 4 } & $\begin{array}{l}\text { Keramahan pegawai terhadap } \\
\text { konsumen }\end{array}$ & D2 \\
\cline { 3 - 4 } & Etika berbicara terhadap konsumen & D3 \\
\hline \multirow{4}{*}{ E } & $\begin{array}{l}\text { Desain atau tema bangunan Oksigen } \\
\text { Coffee bagus dan menarik }\end{array}$ & E1 \\
\cline { 3 - 4 } & Tangibles & Promosi atau diskon yang menarik & E2 \\
\cline { 3 - 4 } & & Harga yang terjangkau & E3 \\
\cline { 3 - 4 } & Kerapihan penampilan pegawai & E4 \\
\cline { 3 - 4 } & $\begin{array}{l}\text { Ketersediaan fasilitas (Ac, Musholah, } \\
\text { Wifi dan Toilet) }\end{array}$ & E5 \\
\cline { 3 - 4 } & Ketersediaan hiburan musik & E6 \\
\hline
\end{tabular}

4. Kriteria tingkat kesesuaian, dapat dilihat pada Tabel 4 :

Tabel 4. Kriteria Tingkat Kesesuaian

\begin{tabular}{|c|c|c|}
\hline No & Kriteria Kesesuaian & Nilai \\
\hline 1 & Sangat Sesuai & $>100$ \\
\hline 2 & Sesuai & $=100$ \\
\hline 3 & Kurang Sesuai & $<100$ \\
\hline
\end{tabular}

\subsection{Rancangan Sistem}

Use Case Diagram digunakan untuk menggambarkan fungsi atau fitur yang terdapat didalam aplikasi yang diusulkan oleh penulis, serta siapa saja aktor atau user yang berhak menggunakan fungsi atau fitur tersebut. Sebagai berikut :

a. Use Case Diagram Konsumen

Keterangan :

1) No. Use Case : 1

2) Nama Use Case : Konsumen

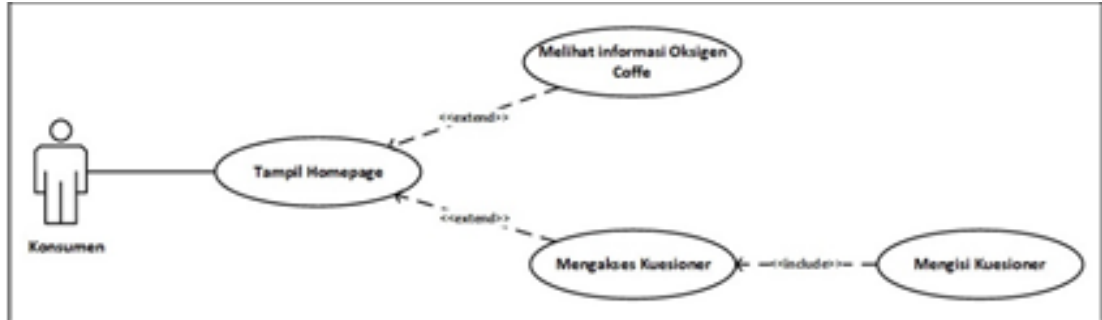

Gambar 2. Use Case Diagram Konsumen

b. Use Case Diagram Bag. Operasional

Keterangan :

1) No. Use Case :2 
2) Nama Use Case : Bag. Operasional

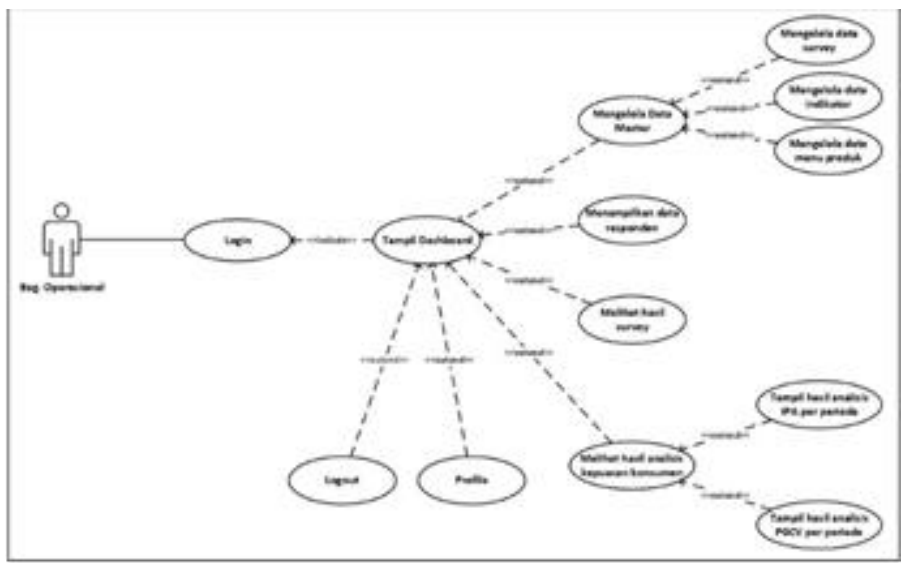

Gambar 3. Use Case Diagram Bag. Operasional

\subsection{Implementasi Sistem}

Implementasi sistem dilakukan menggunakan bahasa pemrograman PHP serta framework CodeIgniter, dan penyimpanan menggunakan MySQL.

\subsubsection{Implementasi Halaman Konsumen}

Pada saat konsumen mengakses aplikasi tidak melalui proses validasi akun user, karena sistem akan langsung menampilkan homepage. Didalam aplikasi tersebut user dapat mengakses 3 menu pilihan yang tersedia, yaitu : home, about us dan questionnaire.

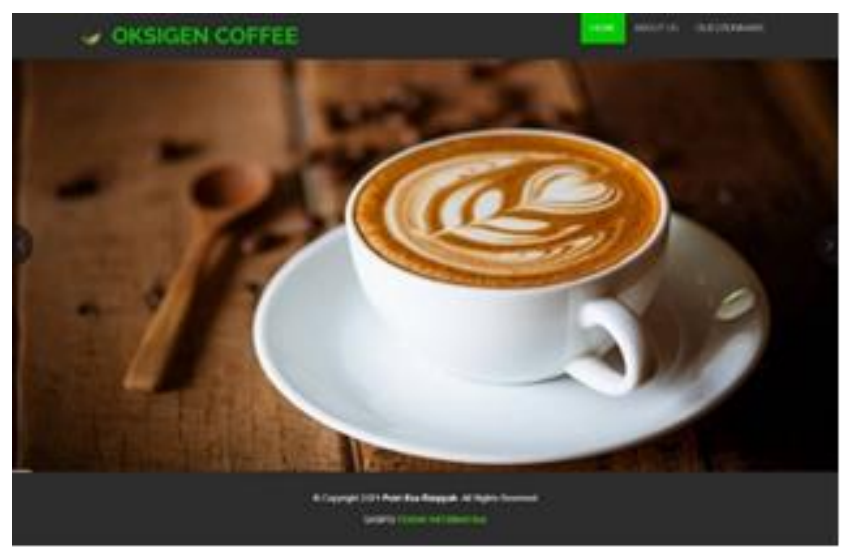

Gambar 4. Halaman Home
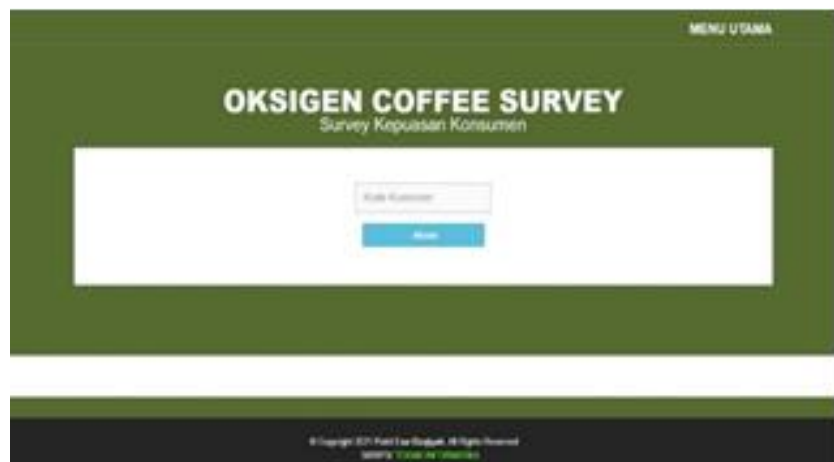

Gambar 5. Halaman Akses Questionnaire 


\section{Keterangan :}

Tampilan pada gambar 5, merupakan halaman validasi kode yang sudah disediakan oleh Bag. Operasional agar konsumen dapat melakukan pengisian kuesioner, menggunakan kode sebagai upaya untuk menghindari pengisian kuesioner oleh pihak lain diluar konsumen dari Oksigen Coffee.

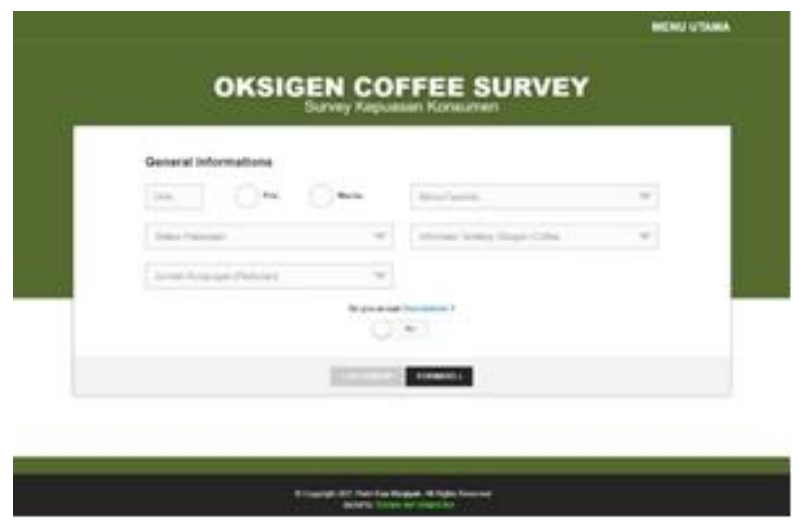

Gambar 6. Halaman Questionnaire Tahap 1

Keterangan :

Tampilan pada gambar 6, jika konsumen sudah berhasil memasukkan kode validasi maka sistem akan menampilkan halaman tahap 1 pengisian kuesioner yang didalamnya konsumen diwajibkan mengisi informasi umum terlebih dahulu, dan mengubah status menjadi "Yes" sehingga konsumen dapat klik tombol forward untuk melanjutkan ke tahap 2 yaitu penilaian kuesioner.

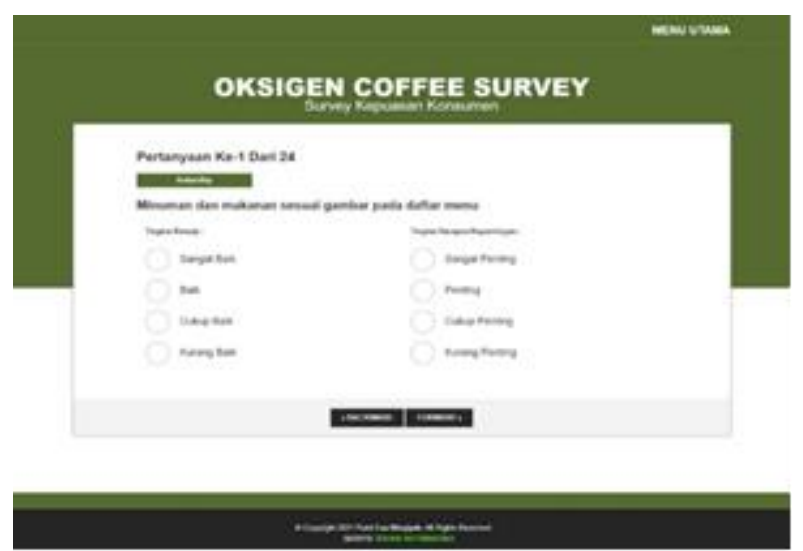

Gambar 7. Halaman Questionnaire Tahap 2

\section{Keterangan :}

Tampilan pada gambar 7, halaman ini menampilkan 24 pertanyaan berdasarkan masingmasing indikatornya serta terdapat 2 bagian penilaian yaitu penilaian tingkat kinerja dan tingkat harapan/kepentingannya, konsumen dapat klik forward untuk melanjutkan ke pertanyaan selanjutnya dan klik backward untuk melihat jawaban pada halaman sebelumnya. 

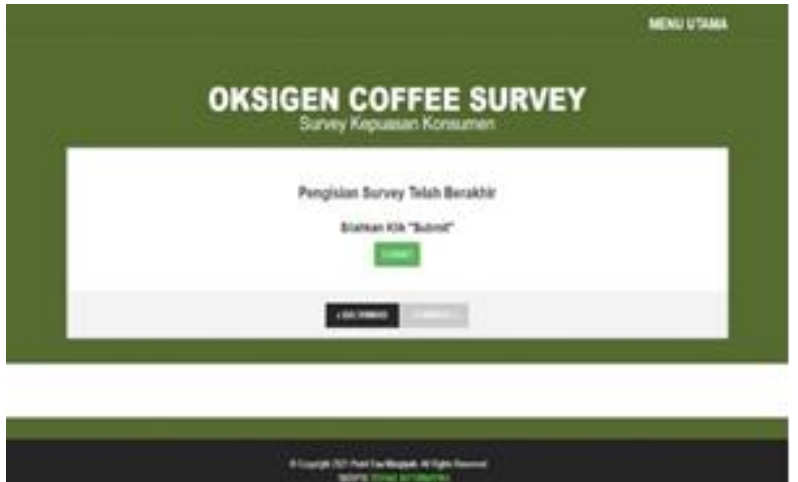

Gambar 8. Halaman Submit Questionnaire

Keterangan :

Tampilan pada gambar 8, jika konsumen telah menyelesaikan pengisian kuesioner hingga akhir maka sistem akan menampilkan halaman submit dan konsumen diwajibkan klik tombol submit agar sistem dapat merekam data penilaiannya.

\subsubsection{Implementasi Halaman Bag. Operasional}

Form ini merupakan tampilan pertama pada aplikasi, pada form ini Bag. Operasional diwajibkan memasukkan username dan password yang telah disediakan untuk mengakses hak akses sebagai admin. Pada pembahasan untuk Bag. Operasional hanya menampilkan implementasi metode Importance Performance Analysis (IPA) dan Potential Gain in Customer Value (PGCV), sebagai berikut :

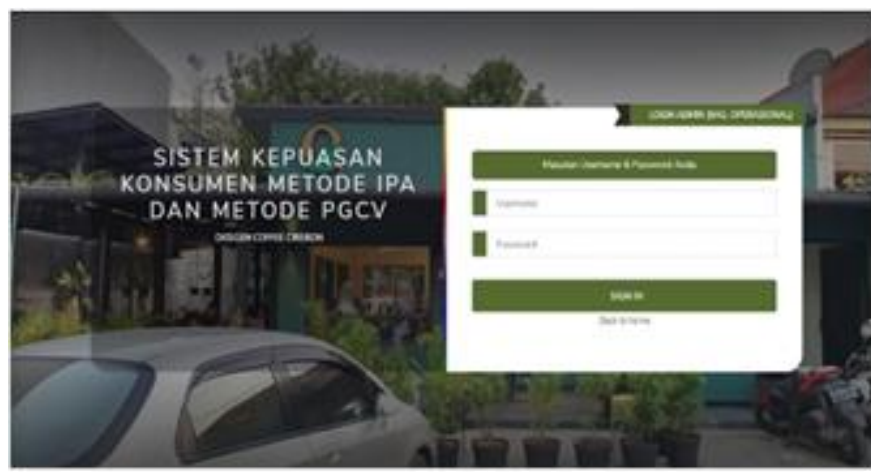

Gambar 9. Halaman Login

a. Implementasi Metode Importance Performance Analysis (IPA)

Pada halaman analisis kepuasan IPA (Importance Performance Analysis) menampilkan hasil pengukuran kepuasan konsumen berdasarkan bulan dan tahun yang terbagi pada beberapa tahap seperti : tahap 1, tahap 2, tahap 3, pemetaan atribut, dan grafik bubble yang menampilkan keseluruhan atribut berdasarkan kuadrannya 


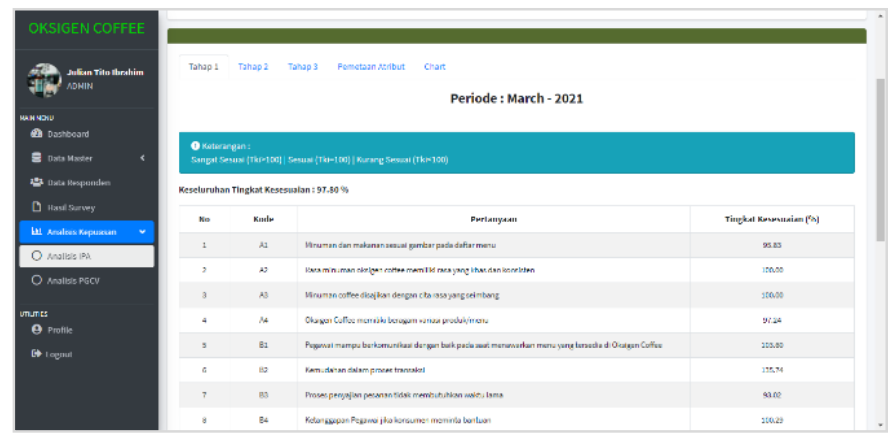

Gambar 10. Halaman IPA Tahap 1

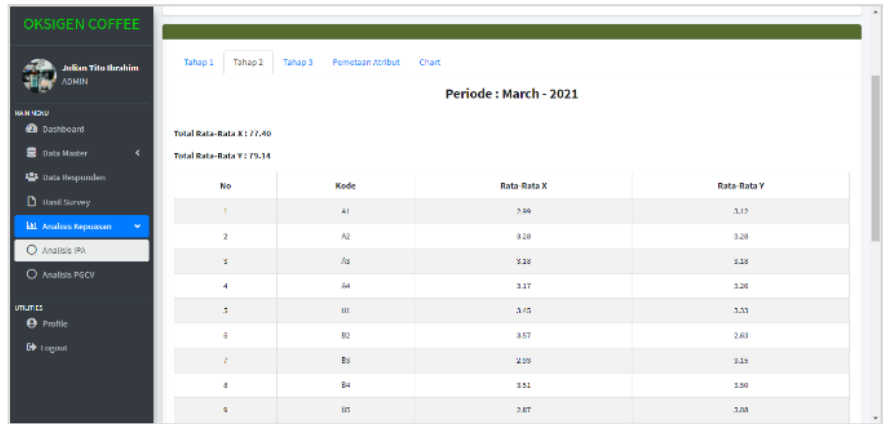

Gambar 11. Halaman IPA Tahap 2

Keterangan :

Tampilan pada gambar 10, menampilkan nilai keseluruhan tingkat kesesuaian $97.80 \%$ yang berarti masih kurang sesuai dan beserta tabel nilai tingkat kesesuaian masing-masing atributnya. Sedangkan pada gambar 11, menampilkan nilai total rata-rata variabel X (kinerja) dan variabel Y (kepentingan atau harapannya), beserta rata-rata masing-masing atribut.

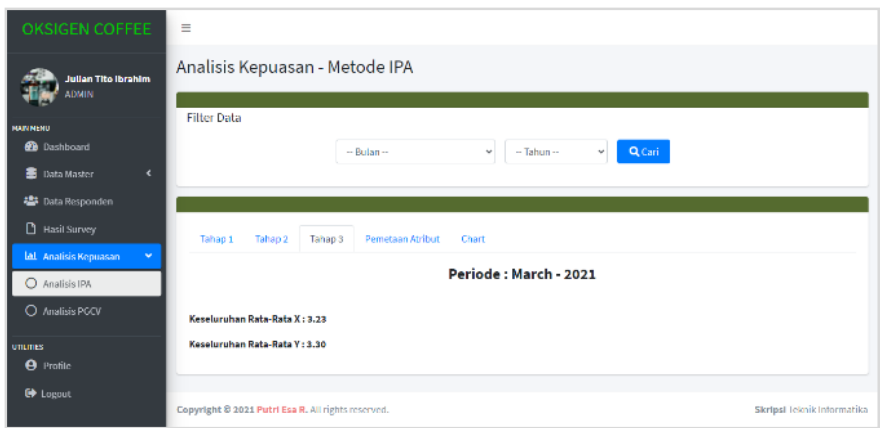

Gambar 12. Halaman IPA Tahap 3

Keterangan :

Tampilan pada gambar 12, menampilkan tahap 3 yaitu nilai keseluruhan rata-rata variabel $\mathrm{X}$ dan variabel $\mathrm{Y}$ yang akan menjadi batasan dalam menentukan atribut pada diagram kartesius kuadran. 


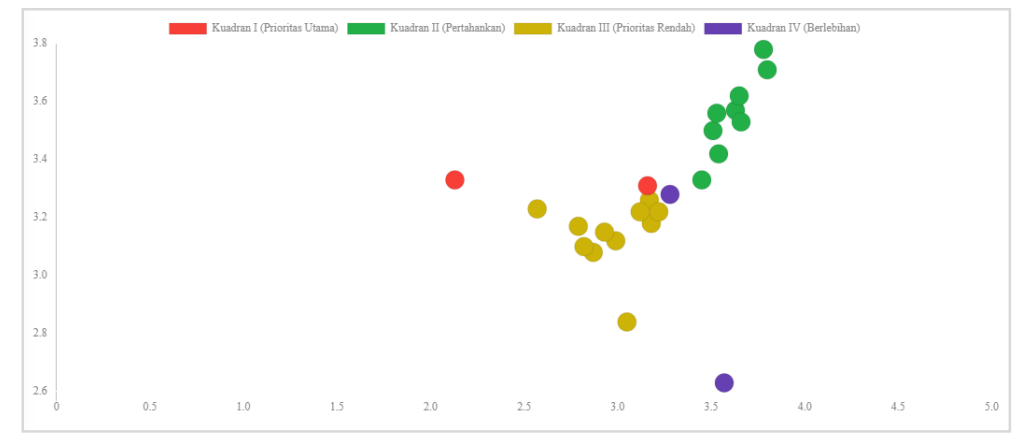

Gambar 13. Bubble Chart Pemetaan Kuadran

Keterangan :

Tampilan pada gambar 13, menampilkan grafik bubble keseluruhan atribut berdasarkan kuadrannya sesuai dengan data pada tabel tahap pemetaan kuadran.

b. Implementasi Metode Potential Gain in Custome Value (PGCV)

Pada halaman analisis kepuasan PGCV (Potential Gain in Customer Value) menampilkan hasil pengukuran kepuasan konsumen berdasarkan bulan dan tahun yang terbagi pada beberapa tahap seperti : tahap 1 - tahap 3, perankingan atribut dan grafik perankingan.

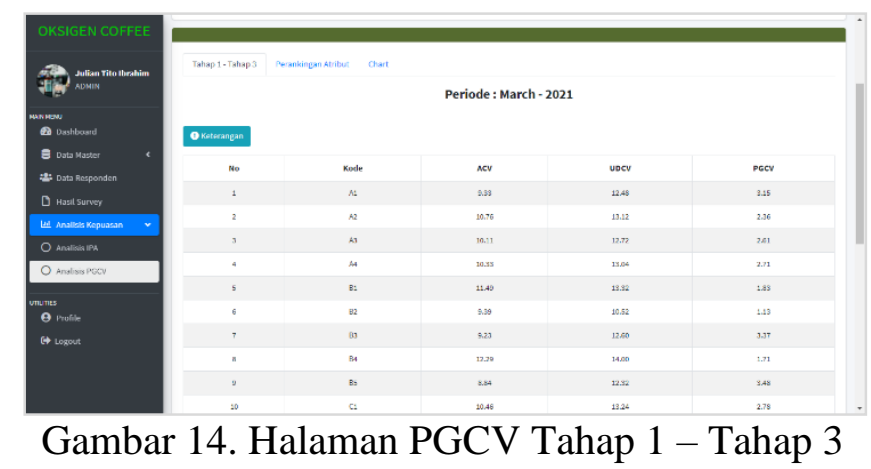

Keterangan :

Pada gambar 14, menampilkan hasil dari tahap 1, tahap 2 dan tahap 3 perhitungan metode Potential Gain in Customer Value (PGCV) masing-masing atribut yang terdiri dari : nilai Achive Customer Value (ACV), Ultimate Desire Customer Value (UDCV) dan hasil perhitungan akhir nilai potential Gain in Customer Value (PGCV).

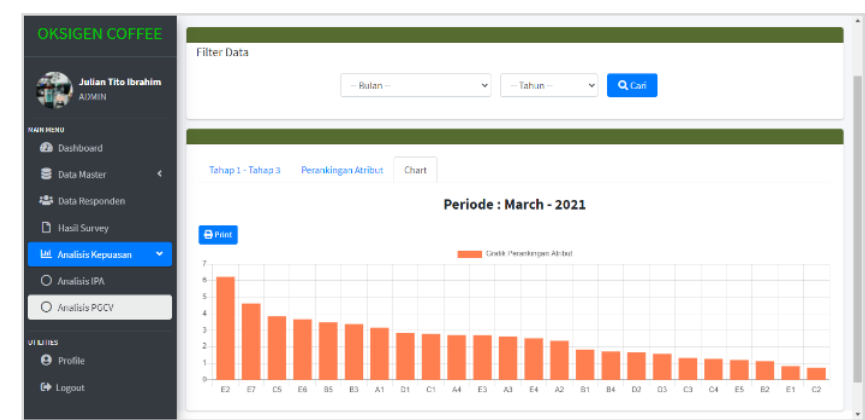

Gambar 15. Perankingan Atribut

Keterangan : 
Pada gambar 15, menampilkan hasil akhir yaitu urutan dari atribut berdasarkan nilai potensial yang didapatkannya dari pengukuran tingkat kepuasan konsumen menggunakan metode Potential Gain in Customer Value (PGCV), dan merupakan hasil akhir Pengukuran Tingkat Kepuasan Konsumen Coffee Shop yang menampilkan urutan atribut yang diprioritaskan untuk diperbaiki atau ditingkatkan, hasil ini dapat dijadikan sebagai laporan yang valid digunakan sebagai landasan perbaikan.

\subsection{Pengujian User Acceptance User}

User Acceptance Test (UAT) merupakan pengujian yang dilakukan secara objektif dengan cara program aplikasi diuji secara langsung oleh pihak yang menggunakan aplikasi pengukuran tingkat kepuasan konsumen Coffee Shop ini secara langsung. Pengujian aplikasi ini dilakukan oleh 20 user (perwakilan 2 pegawai Oksigen Coffee dan konsumen), dengan hasil sebagai berikut :

Tabel 5. Rekapitulasi Penilaian UAT

\begin{tabular}{|c|c|c|c|c|c|}
\hline \multirow{2}{*}{ No } & \multirow{2}{*}{ Pertanyaan } & \multicolumn{4}{|c|}{ Presentase Penilaian (Skor) } \\
\hline & & 4 & 3 & 2 & 1 \\
\hline 1 & $\begin{array}{l}\text { Apakah tampilan aplikasi berbasis web ini } \\
\text { menarik? }\end{array}$ & $\begin{array}{c}28 \\
(42 \%)\end{array}$ & $\begin{array}{c}39 \\
(58 \%)\end{array}$ & 0 & 0 \\
\hline 2 & $\begin{array}{l}\text { Apakah sistem ini mudah untuk dimengerti } \\
\text { dan mudah digunakan? }\end{array}$ & $\begin{array}{c}24 \\
(37 \%)\end{array}$ & $\begin{array}{c}39 \\
(60 \%)\end{array}$ & $\begin{array}{c}2 \\
(3 \%)\end{array}$ & 0 \\
\hline 3 & $\begin{array}{l}\text { Apakah pertanyaan pada kuesioner telah } \\
\text { sesuai standar materi yang diperlukan untuk } \\
\text { survei kepuasan konsumen? }\end{array}$ & $\begin{array}{c}16 \\
(27 \%)\end{array}$ & $\begin{array}{c}36 \\
(60 \%)\end{array}$ & $\begin{array}{c}8 \\
(13 \%)\end{array}$ & 0 \\
\hline 4 & $\begin{array}{l}\text { Apakah penilaian efektif dengan melibatkan } \\
\text { penilaian tingkat kepentingan atau harapan } \\
\text { dari konsumen, selain penilaian kinerja? }\end{array}$ & $\begin{array}{c}36 \\
(53 \%)\end{array}$ & $\begin{array}{c}30 \\
(44 \%)\end{array}$ & $\begin{array}{c}2 \\
(3 \%)\end{array}$ & 0 \\
\hline 5 & $\begin{array}{l}\text { Apakah sistem ini memberikan kemudahan } \\
\text { jika dibandingkan dengan cara manual? }\end{array}$ & $\begin{array}{c}40 \\
(57 \%)\end{array}$ & $\begin{array}{c}30 \\
(43 \%)\end{array}$ & 0 & 0 \\
\hline 6 & $\begin{array}{l}\text { Secara keluruhan sistem, apakah sistem ini } \\
\text { sudah sesuai dengan kebutuhan untuk } \\
\text { mengetahui kepuasan konsumen secara } \\
\text { terukur? }\end{array}$ & $\begin{array}{c}56 \\
(76 \%)\end{array}$ & $\begin{array}{c}18 \\
(24 \%)\end{array}$ & 0 & 0 \\
\hline
\end{tabular}

Dari hasil pengujian pada tabel 5, maka telah didapatkan nilai persentase tingkat kesesuaian sistem yang dihasilkan dari pembagian antara skor penilaian dengan skor ideal, yaitu sebagai berikut :

$$
\begin{aligned}
\text { Kesesuaian } & =\frac{\text { Total Skor }}{\text { Skor Ideal }} \times 100 \%=\frac{((7 \times 4)+(13 \times 3)+\cdots+(14 \times 4)+(6 \times 3))}{(20 \times 4) \times 6} \\
= & \frac{404}{480} \times 100 \%=84.17 \%
\end{aligned}
$$

Berdasarkan hasil pengujian menggunakan User Acceptance Test (UAT) terhadap 20 user Oksigen Coffee, maka telah didapatkan persentase tingkat kesesuain sebesar $84.17 \%$ yang artinya aplikasi yang telah dibangun telah sesuai dengan kebutuhan serta perancangannya. 


\section{Kesimpulan}

Aplikasi yang telah dibuat dapat diterapkan di Oksigen Coffee untuk mengetahui tingkat kepuasan konsumen sehingga dapat mempercepat pihak manajemen dalam meningkatkan layanan sesuai dengan point-point kekurangan yang menyebabkan ketidakpuasan konsumen. Penerapan metode IPA digunakan untuk mengetahui atribut yang harus diperbaiki atau dikurangi berdasarkan pemetaan kuadrannya dan persentase pemetaan kuadran yang dihasilkan dari metode IPA dengan 24 atribut yang terbagi menjadi 4 kuadran yaitu kuadran I (prioritas utama) sebesar 8.33\%, kuadran II (pertahankan prestasi) sebesar $37.50 \%$, kuadran III (prioritas rendah) sebesar 45.83\%, dan kuadran IV (berlebihan) sebesar 8.33\%. Sedangkan metode PGCV digunakan untuk menghasilkan urutan prioritas atribut yang harus diperbaiki berdasarkan nilai potensial yang didapatkannya dan posisi atribut yang mendapatkan rank ke 1 adalah E2 (promosi atau diskon yang menarik) mendapatkan nilai potensial 6.23, artinya promosi atau diskon tersebut harus ditingkatkan agar menarik lebih banyak konsumen.

\section{Daftar Pustaka}

[1] K. Sari, “Artikel," Potensi Kopi Indonesia, 2020, [Online]. Tersedia: https://thecolumnist.id/artikel/potensi-kopi-indonesia-1369.

[2] T. Redaksi, "Berita", Kedai Kopi di Indonesia Hampir Mencapai 3000 Gerai, 2019, [Online]. Tersedia: https://voi.id/berita/925/kedai-kopi-di-indonesia-hampir-mencapai3-000-gerai.

[3] P. A. Ranitaswari, S. Mulyani dan C. A. B. Sadyasmara, "Jurnal Rekayasa dan Manajemen Agroindustri," Analisis Kepuasan Konsumen Terhadap Kualitas Produk Kopi dan Kualitas Pelayanan Menggunakan Metode IPA., vol. 6, no. 2, pp. 147-157, 2018.

[4] P.W. Utomo. "JPTM,” Analisis Kepuasan Pelanggan Terhadap Hasil Kinerja Bengkel Dengan Menggunakan Metode IPA., vol.08, no.01, pp. 135-144, 2019.

[5] C. E. Silalahi, "Analisis Kepuasan Pelanggan Terhadap Kualitas Pelayanan Asuransi Rumah Menggunakan Metode PGCV" Skripsi, Universitas Diponegoro, Semarang, 2012.

[6] A. F. Gucci dan H. Setiawan, "Jurnal Teknik Industri," Pengukuran Indeks Kepuasan Pasien Terhadap Pelayanan dan Penentuan Prioritas Perbaikan di Puskesmas dengan Metode PGCV., vol. 5, no. 3, 2017.

[7] W.K. Ramdhani dan A.L. Yuliati, "Pengaruh Kualitas Pelayanan Terhadap Kepuasan Pelayanan Terhadap Kepuasan Pelanggan Pengguna Jasa Internet," eProceedings of Management, $2016 \quad$ [Online]. Tersedia: https://libraryeproceeding.telkomuniversity.ac.id/index.php/management/article/view/ 3151 [20-Desember-2020].

[8] Administrator, "Kepuasan Pelanggan", Menciptakan Kepuasan, 29 Maret 2017, [Online]. Tersedia: https://mars.umy.ac.id/menciptakan-kepuasan [20-Desember2020].

[9] B. Wahyono, "Pendidikan Ekonomi", Pengertian dan Pengukuran Kepuasan Konsumen, [Online], 2012.

Tersedia: $\mathrm{http}: / / \mathrm{www}$.pendidikanekonomi.com/2012/07/pengertian-dan-pengukuran kepuasan.html [20 Desember 2020].

[10] M.P. Panuntun. “Analisis Kualitas Pelayanan Terhadap Kepuasan Konsumen Dengan Metode IPA dan PGCV” Skripsi, Universitas Brawijaya, Malang, 2015.

[11] Sukamto, R. Ariani dan M. Shalahuddin, Rekayasa Perangkat Lunak. Bandung: Informasi Bandung, 2016. 